\title{
Assessing the Level of Food and Beverage Patronage by Local and International Tourist in the New Juaben Municipality of the Eastern Region of Ghana
}

\author{
J. Adanse ${ }^{1}$, S. Antwi-Boasiako ${ }^{2}$, A. C. Atinga ${ }^{3}$, L. T. Yamga ${ }^{4}$ \\ ${ }^{1}$ Bolgatanga Polytechnic, P. O. Box 767, Bolgatanga, Upper East Region, Ghana, Department of Hospitality Management \\ ${ }^{2}$ Department of Hospitality Management, Tamale Technical University, P. O. Box 3, Tamale, Ghana \\ ${ }^{3}$ Bolgatanga Polytechnic, P. O. Box 767, Bolgatanga, Upper East Region, Ghana, Department of Hospitality Management \\ ${ }^{4}$ Bolgatanga Polytechnic, P. O. Box 767, Bolgatanga, Upper East Region, Ghana, Department of Hospitality Management
}

\begin{abstract}
Food consumption is recognised as an assemblage of appropriate and changing social practice, where food no longer only assists as sustenance but also a way to relate to other people in social, cultural and political terms. The study assessed level of food and beverage patronage by local and international tourist in the New Juaben Municipality of the Eastern Region of Ghana. Descriptive survey approach of qualitative research was used. Purposive sampling technique was used to select four restaurants which are highly patronised by both international and local tourists. The study population was made up of international tourists, and indigenous Ghanaians of all the four selected restaurants. One hundred and forty-four (144) respondents were selected by the simple random process. Questionnaires were developed and administered among the above mentioned respondents at the selected restaurants personally. Data analysis was performed using Statistical Package for the Social Sciences (SPSS) version 20. The data was analysed using descriptive methods of analysis. The responses were recorded in frequencies and percentages. The study revealed that majority (67.9\%) of the Ghanaian respondents patronized local foods as compared with continental foods in the various restaurants whilst (68\%) of the international tourists had high affection for local foods. The study recommended that Restaurant Managers and Chefs should design flexible menus that are of quality but affordable to offer Ghanaian tourists the opportunity to taste or consume indigenous dishes.
\end{abstract}

Keywords: Food consumption, Beverage, Tourism, Koforidua, Restaurant, Ghanaian Tourist, Managers

\section{Introduction}

Food consumption is recognised as aassemblage of appropriate and changing social practice, where food no longer onlyassists as sustenance but also a way to relate to other people in social, cultural and political terms[1]. It also serves as a way for meeting and experiencing other food ways and cultures [2], [3]. Some studies have shown that tourists travel to destinations that have established a reputation as a location to experience quality local products or cuisines [4], [5], [6].Therefore Local foods or cuisines that are exceptional to an area can be one of the unique sources that may be used as marketing tools to get more visitors.

On the other hand, food provides energy and vital nutritional componentsrequired for body functions, and thus, eating is at the same time consideredas a 'compulsory' tourist activity [7]. Food is an extremely important part of the culture of a region. Furthermore, eating is part of the tourist experience [8]. Tourists' spending on food can constitute up to one-third of the total tourist expenditure [9], [6], thus comprising a significant proportion of tourism revenue. According to [10], the 'world's population have increased, therefore have exposure to a wider variety of ethnic dishes and products, thus this trend may stimulate a greater demand for local speciality products and indigenous cuisines.
Researchers and hospitality industries have only recognized the link between food, culture and tourism after the mid1990s. From an economic point of view, food is a physiological necessity that is why we can easily argue that nearly $100 \%$ of tourists spend money for food where they go for holiday or trip[11 ].Food in tourism can result in benefits for both hosts and guests[12], [13], [14]. More specifically, it is recognized that the kind of foods and drinks on offer for tourists could be a great medium for differentiating destinations. The new tourists seek food and beverage combinations and eating experiences that foster learning, therefore, food preparation and related services contribute substantially to tourism employment[12]. The maximization of relationship between host and tourist by means of locally produced food will increase the potential contribution of tourism to regional development [15]. [14] lists interest in local food by tourist and its effects on tourism in three levels; firstly, increased tourist consumption of local foods will support local economy. Secondly, buying local products will reduce the carbon footprint. Third, promoting local food products is one way to distinguish the destination among other competitors and attract a stable stream of visitors. However, while growing importance of food for destination is obvious, not all destinations try to use food in marketing activities to get potential opportunities it provides [16], [13], [14]. According to [17], "local food is a centralconstituent of a destination's features, adding to the range of attractions and the overall tourist experience". In the field of hospitality

Volume 6 Issue 7, July 2017 www.ijsr.net 


\section{International Journal of Science and Research (IJSR) \\ ISSN (Online): 2319-7064}

Index Copernicus Value (2015): 78.96 | Impact Factor (2015): 6.391

and tourism, there have been numerousefforts to regulate and examine the factors prompting tourists to local food consumption in a tourist destination [18], [19], [20]. However, there is no study, which includes determination of local foods of the destination, inclusion level of local food of the destination in restaurants menus and the determination of tourist motivations, which is related to local food consumption. Food is animportant means to enter into another culture asit allows an individual to experience the 'Other' on a sensory level, and not just an intelligent one". The importance of local cuisines to tourists today is demonstrated by the results of a survey of visitors to Yucatan Peninsula where $46 \%$ of the meals consumed by the tourists were local cuisines [10].

The growth of special interest in tourism is seen as a reflection of the increasing diversity of leisure interests of the early twenty-first century leisure society[21]. The growth of culinary tourism is seen as an outcome of a trend where people spend much less time cooking, but choose to pursue their interest in food as a part of a leisure experience such as watching cooking shows and dining out [22].

According to [23], eating and drinking is eventually cultural affairs hence the culinary tourist is also a cultural tourist. Thus, the clearedge of food as a special concentrationfactor as well as a cultural component makes the culinary tourist probably both a special interest tourist and a cultural tourist.

[24], Asserted that, studies of consumer behaviour in the area of food tourism are rare and as a result, the picture we have of the food tourist, is at best sketchy, and considerable amount of research is required to understand food tourism consumer behaviour more effectively. To date, the material that does exist has been borrowed from more general tourism studies or has been inferred from studies not directly related to tourism [11]. Preparation of foods and beverages on the journeys is one of the most important parts involved in the tourism industry. As Ghanaian foods and beverages are to a great extent still unfamiliar even to the Ghanaians, concrete measures should be taken to make them known to everybody. By suitable presentation of these foods and beverages and by using a proper information system, not only a great part of Ghanaian cultural heritage will be unravelled, but also a variable collection of foods will be brought about in the local restaurants and this in return will help satisfy the customers and to provide the people active in the industry with substantial investment. It is important to notice that, food as a source of tourism attraction is neglected in eastern region of Ghana, and therefore this study take into consideration that the local food of each region is one of the emblems of that region's culture. Despite the importance of food consumption in the context of tourism, little is known about the phenomenon in general, and from the sociological perspective in particular [25].In the field of hospitality and tourism, there have been various attempts to determine and examine the factors influencing tourists to local food consumption in a tourist destination [18], [19],[20]. However, there is inadequate information on factors that influence local foods consumption by tourist in Ghana and hence the current study which seek to identify the factors that influence consumption of local food and beverages by local and international tourists in the New Juaben Municipality and its environs.

\section{Materials and Methods}

The study adopted the descriptive survey approach of qualitative research. According to [26] survey can be used as a primary data collection technique. [27] Also adds that surveys are popular as they allow the collection of data in a highly economical way. The researcher believes this is the best strategy because it is fast, inexpensive, and easy to explain.

\subsection{Study location}

The study was conducted in the New Juaben Municipal area of the Eastern Region of Ghana. The municipality covers an estimated area of 110 square kilometres, constituting $0.57 \%$ of the total land area of the Eastern Region. The New Juaben municipality shares boundaries with East-Akim Municipality to the northeast, Akwapim North District to the east and south and Suhum-Kraboa-Coaltar District to the west. Koforidua is the capital city of New Juaben Municipality and Eastern region. It is located between Latitude $^{\circ} 10^{\prime} 58^{\prime \prime} \mathrm{N}$ and Longitude $0^{\circ} 18^{\prime} 11$ " W.Population range is between 50,000 and 100,000 .

\subsection{Population for the study}

The purposive sampling technique was used to select four restaurants which are highly patronised by both international and local tourists. The selected restaurants areLindaDor restaurant, Bedtime hotel\& restaurant, Mac-Dic Plaza\& restaurant, and St. James hotel\& restaurant in Koforidua, the capital of Eastern Region of Ghana.

The study population was made up of international tourists, indigenous Ghanaians of all the four selected restaurants. One hundred and forty-four (144) respondents were selected by the simple random process. The sample consists of fifty (50) international tourists, and eighty four (84) local tourists. Questionnaires were developed and administered among the above mentioned respondents at the selected restaurants personally. In some cases interviews were conducted alongside the administration of the questionnaires where necessary, as a means of assisting the respondents to understand the content of the questions and be interested in the exercise.

\subsection{Profile of the restaurants}

\subsubsection{Mac-Dic Royal Plaza Hotel Restaurant}

Mac-Dic Royal Plaza Hotel\& Restaurant is a 3-star deluxe hotel located in koforidua, $80 \mathrm{~km}$ drive from Accra. It offers a warm and friendly atmosphere due to the location with modern comfort and hospitality you would expect from an international standard hotel.

The hotel offers 40 spacious air conditioned rooms and is tastefully decorated to create a cozy and relaxing atmosphere. It also has 5 conference halls, banquet hall, a tennis court, swimming pool, night club, children playground, unisex salon, resident band, indoor and outdoor

\section{Volume 6 Issue 7, July 2017 www.ijsr.net}




\section{International Journal of Science and Research (IJSR) \\ ISSN (Online): 2319-7064}

Index Copernicus Value (2015): 78.96 | Impact Factor (2015): 6.391

restaurants, bar, a perfect blend to meet family, corporate and conference visitors. The rooms are equipped with wireless internet access, self-controlled air-condition, Telephone, Satellite TV, Refrigerator, a separate bathroom with corner bathtub and toiletries, mini bar, and spacious balconies with view to the pool. It is also a peaceful place for holiday makers seeking real rest and relaxation close to nature and an ideal place for walkers and botanists. The restaurant offers a $24 \mathrm{hr}$ meal service to clients.

\subsubsection{Linda Dor highway rest stop and restaurants}

The Linda Dor restaurants are operated by Madam Arkorfuland the brand has four branches namely: the Linda Dor Plaza, Linda Dor Annex at the premises of the State Insurance Company (SIC) and Linda Dor at the Ghana Telecom area, all in Koforidua, and the other branch in Accra, opposite Rana Motors on the State Transport Company (STC)-Graphic Road bypass. The Linda Dor highway rest stop and restaurant at Bunso junction is conveniently located in between Ghana's two major cities: Accra and Kumasi. It therefore serves as the perfect place to freshen up whilst embarking on a journey from any of the two cities to the other. Many buses that travel on that road use the restaurant as their mandatory rest stop for passengers to purchase various cuisines from their magnificent traditional and continental restaurants.

\subsubsection{Bedtime hotel\& restaurant}

Bedtime Hotel \& restaurantis a 3-Star facility operating a $24 \mathrm{hr}$ restaurant and bar. The strategic location of this facility in the outskirts of the City, on the Polytechnic Highway makes it easily accessible for guests and affords them the convenience of travelling around easily without having to face the chaos of long traffic jams as witnessed by guests in hotels located in and around the city centre.The Hotel has 92 luxuriously elegant rooms with décor. These include 5 chalets for honeymoon and VIPs, 84 Executive Rooms and 3 Single Rooms. Other facilities include Swimming Pool, a Gym, Conference Rooms, Restaurant and an Executive Lounge. The restaurant offers both local and continental cuisines.

\subsubsection{St. James Hotel\& restaurant}

The Hotel\& restaurant has excellent location, unsurpassable service and great dining. The St. James Hotel is located in a calm ambiance in Koforidua, Ghana. The house has eight rooms providing 24 hour room service, free WIFI and satellite television in all rooms. There is a restaurant, a bar, Internet Cafe and Conference Hall, Standby modern electricity generators and $24 \mathrm{hr}$ security services. The Hotel restaurant serves a variety of dishes in menu options daily. Breakfast is surcharged. There is an outdoor bar where guests can order various alcoholic and non-alcoholic drinks.

\subsection{Statistical Analysis}

Data analysis was performed using Statistical Package for the Social Sciences (SPSS) version 20. The data was analysed using descriptive methods of analysis. The responses were recorded in frequencies and percentages.

\section{Analysis and Discussions}

\subsection{Demographics of the study participants}

For international guest, $64 \%$ were females and $36 \%$ males. The age range which had the least number of respondents were 21-25 yearswith $2 \%$ and the age range with highest respondents were $26-30$ year with $46 \%$. The mean age was 3.46 and standard deviation of 1.446. Fifty six percent were single while $44 \%$ were married.This shows that most of the foreign guestswho patronized the restaurants were women.

For indigenous Ghanaians, $47.6 \%$ were females while $52.4 \%$ were males. The respondents who were between ages 16-20 years were $3.6 \%$. Majority of the respondents were between the ages of $36-40$ years with a share of $41.7 \%$. The mean age was 4.62 and standard deviation of 1.26 . About $51.2 \%$ were also single whilst $48.8 \%$ were married. In contrast with international guests, more males seem to visit restaurants than females. A major reason accounting for this phenomenon is that, the Ghanaian women preferred to cook their own meals than to purchase from restaurants, their male counterparts on the other hand preferred to eat from restaurants than to cook. The women only patronise from restaurants only when they travel.

\subsection{Analysis of International tourists}

A total of 50 international tourists at the selected restaurants answered the questionnaire. Most of the guests were from UK and few numbers from china and France as shown in figure 1. This shows that most of the tourists in Koforidua are from Britain and easy communication might account for it.

\subsubsection{International tourists' choice of cuisine}

Thirty-four respondents representing $68 \%$ of the tourists had high affection for local foods while $32 \%$ preferred continental dishes as shown in Table 1. Some of the international tourists indicated that they are in Ghana to taste their cuisines and as such saw no reason in eating continental dishes which they are already familiar with.

Forty-eight respondents representing $48 \%$ of the tourists preferred Banku and Okro soup and Beer while $32 \%$ enjoyed eating Fufu\&abunuabunu. An appreciable number of the respondents $(48 \%)$ were of the view that they take banku and okro soup because of its unique characteristics it possess, such as methods of preparation, flavour, sliminess of the okro and presentation. They added that, whenever they are in Ghana, they purchase Banku and Okro soup more than any other food.

With regard to the beverages consumed, fifteen respondents representing $30 \%$ consumed beer while Pito was the least beverages consumed with $8 \%$. It was revealed in the interview that beer which was the highest beverage consumed by the international tourist is almost produced in all the countries and that, it is a well-known beverage item and has been certified by the food and drug Authority in which its content is trusted. They again, asserted that, the way local beverages are packaged in used containers and bottles discouraged them from consuming it the more. 


\section{International Journal of Science and Research (IJSR) \\ ISSN (Online): 2319-7064}

Index Copernicus Value (2015): 78.96 | Impact Factor (2015): 6.391

With reference to "what motivated the international tourists to purchase local foods", 17 respondents representing 34\% indicated that they are motivated by the excellent customer relationships while $24 \%$ claimed they are motivated by the familiarity with the culture and might have been here many times. It was evident that staffs who work in these Ghanaian restaurants are well trained. In spite of that, they understand customer care concept and this generous treatment encourage them to visit a particular restaurant.

Thirty-eight respondents $38(76 \%)$ were of the view that they are aware of ingredients used in the preparation of a particular dish before they purchase while the rest $24 \%$ of the respondents claimed they have no idea about the ingredients used in producing a particular dish. Majority of the international tourists disclosed that some of the restaurants write the main ingredients under each dish in the menu card. Others also explain the ingredients used in preparing a particular dish and this help them to select a particular type of cuisine.

With regard to the level of appetite for local foods, thirtytwo respondents with $64 \%$ said that they have high level of appetite for the local cuisines while $8 \%$ had the least level of appetite for the local foods. Some of the tourists indicated that Ghanaian cuisines are hygienically prepared and comes with a peculiar taste and aroma. In spite of that, anytime they visit Ghana they purchase local foods than the continental foods.

\subsection{Indigenous Ghanaians choice of cuisine}

Participants were asked about the region they are from. Out of the eighty four Ghanaians who answered the questionnaire, Greater Accra was the highest with 26.2\%, Ashanti with $17.9 \%$, Eastern with $16.7 \%$, Volta and western with $14.3 \%$ and the lowest being Northern region with $10.7 \%$ as shown in (figure 5). It is clear that Koforidua is a cosmopolitan city.

Majority of the Ghanaian respondents patronized local foods as compared with continental foods in the various restaurants. Fifty seven (57) representing $67.9 \%$ out of the 84 participants consumed local dishes while 27 (32.1\%) preferred continental dishes. This might be due to the lower prices of the local foods and familiarity with it. Banku and Okro soup is the most patronized followed by kokonte and palm nut soup in koforidua municipality.

Majority of the respondents revealed that local cuisines are their delicacies and as such, the ingredients are grown and cultivated in the country, therefore they saw no need of purchasing continental dishes.

With regard to the type of local food consumed by the indigenous Ghanaians, 24 respondents representing 28.6\% revealed that they consume Banku and Okro soup while 19 (22.6\%) respondents preferred kokonte and palmnut soup and the least food consumed was Fufu and abunuabunu soup. An appreciable number of the respondents purchase banku and okro soup because about fifty percent of people living in Juaben and its environs are Ga's and Ewe's and it is a native staple food in both regions, therefore have good appetite for meals prepared from maize and okro.

Twenty respondents representing $23.8 \%$ preferred palm wine and other beverages while 18 respondents with $21.4 \%$ consumed asana. The least beverage consumed was Akpeteshie with a percentage of 8.3. Some of the respondents indicated that many people in the municipality are into palm wine production and as a result of that palm wines are very affordable and easy to get.

Twenty-three respondents revealed that price affordability and familiarity with culture motivates them to patronise local foods with of $27.4 \%$ respectively while 20 respondents indicated that they are motivated by the deliciousness of the food. The results from the interview revealed that indigenous Ghanaians who patronise local foods are price sensitive hence buy a particular meal that has a lower pricing. They added that some meals are also purchased during festive occasions because such foods are specially prepared to suit the event.

Seventy-two respondents representing $85.7 \%$ purchased cuisines for which they are familiar with their ingredients while $12(14.3 \%)$ respondents did not pay attention to their familiarity with the ingredients used to prepare the particular dish. The interview disclosed that majority of the indigenes prepare such foods in their homes and are familiar with the ingredients and methods of preparing some of the local cuisines they purchase.

Regarding the level of appetite for local dishes, 49 respondents representing $58.3 \%$ indicated high appetite levels while 13 respondents with $15.5 \%$ had very little appetite levels. More than half of the respondents (58.3\%) declared that local foods are their native foods for which they have been enjoying since infancy. They add that the methods of preparation, ingredients and presentation boost up their level of appetites.

\section{Conclusions}

1) From the research conducted, it is clear that both international and Ghanaian tourists patronized local dishes better than continental cuisines. However, Ghanaian tourists prefer local cuisines for which they are familiar with. This familiarity could be from the ingredient used, the method used for preparing the food or the presentation.

2) The Ghanaian tourist is sensitive to the price of cuisine before patronage. They are most likely to go for cuisines with lower prices. This could be due to the low income levels of the local tourists

3) International tourists prefer beverage items that have been branded since these branded beverages have been standardised and certified, making it wholesome for consumption.

\section{Recommendations}

1) Restaurateurs should increase the awareness of tourists on indigenous cuisines through the organization of district and regional durbars to demonstrate new recipes

\section{Volume 6 Issue 7, July 2017 www.ijsr.net}




\section{International Journal of Science and Research (IJSR) \\ ISSN (Online): 2319-7064}

Index Copernicus Value (2015): 78.96 | Impact Factor (2015): 6.391

and methods of preparing a particular type of local cuisines to encourage high patronage.

2) Managers of the Hospitality industries in Ghana should from time to time give in-service training to their personnel to introduce them to new ways of preparing dishes and garnishes.

3) Restaurant Managers and Chefs should design flexible menus that are of quality but affordable to offer Ghanaian tourists the opportunity to taste or consume indigenous dishes.

4) Producers of local beverages ought to standardize and certify their products through innovative branding, making them appealing especially to international tourists, thereby increasing their market share.

\section{References}

[1] Oosterveer, P. 'Globalization and sustainable consumption of shrimp': consumers and governance in the global space of flows. International Journal of Consumer Studies, 30(5), 465-476, 2006

[2] Chang, R. C. Y., Kivela, J., \&Mak, A. H. N. 'Food preferences of Chinese tourists'. Annals of Tourism Research, 37(4), 989-1011, 2010

[3] Molz, J. G. 'Eating Difference': The Cosmopolitan Mobilities of Culinary Tourism. Space and Culture, 10(1), 77-93, 2007

[4] Charters, S. and Ali-Knight, J., 'Who is the wine tourist?' Tourism Management, 23(2), pp. 311-319, 2002

[5] Telfer, D. J. 'From a wine tourism village to a regional wine route': An investigation of the competitive advantages of embedded clusters in Niagara, Canada. Tourism Recreation Research, 26 (2), 23-33.Telfer, D.J., and Wall, G. (1996) Linkages between tourism and food production, Annals of Tourism Research, 23 (3), 635-653, 2001b

[6] Hall, C.M., and Macionis, N., 'Wine tourism in Australia and New Zealand'. In: Butler, Telfer, D. J., \& Wall, G. (2000). Strengthening backward economic linkages: local food purchasing by three Indonesian hotels. Tourism Geographies, 2(4), 421-447, 1998

[7] Richards, G. 'Gastronomy': An Essential Ingredient in Tourism Production and Consumption? In A. M. Hjalager\& G. Richards (Eds.), Tourism and Gastronomy(pp. 3-20). London: Routledge. 2002

[8] Hjalager, A. M., \& Richards, G. (Eds.). 'Tourism and Gastronomy'. London: Routledge, 2002

[9] Hall, C.M. \&Sharples, L. 'The consumption of experiences or the experience of consumption?' An introduction to the tourism of taste, In C.M. Hall, L. Sharples, R. Telfer, D. J., \& Wall, G. (2000). Strengthening backward economic linkages: local food purchasing by three Indonesian hotels. Tourism Geographies, 2(4), 421-447, 2003

[10] Torres, R. 'Toward a better understanding of tourism and agriculture linkages in the Yucatan': tourist food consumption and preferences. Tourism Geographies, 4(3), 282-306, 2002

[11] Shenoy, S. S. 'Food tourism and the culinary tourist'. (Doctorate dissertation, Clemson University). Hotel and Restaurant Management (Nummedal and Hall, 2006; Okumus et a. al., 2007; Sims, 2009), 2005

[12] Nummedal, M. \& Hall, C. M. 'Local Food in Tourism': An Investigation Of The New Zealand South Island's Bed And Breakfast Sector's Use and Perception of Local Food. Tourism Review International, Vol.9, No.4, pp.365-378, 2006

[13] Okumus, B.; Okumus, F. and Mckercher, B. "Incorporating local and international cuisines in the marketing of tourism destinations': the cases of Hong Kong and Turkey", Tourism Management, vol. 28, pp. 253-261, 2007

[14] Sims, R. 'Putting place on the menu: the negotiation of locality in UK food tourism', food production to consumption. Journal of Rural studies 30, 1-11. Retrieved October 12, 2012, from www. Science direct.com.Torres, K. L. (2002). Junior World mark encyclopedia of foods and recipes of the world, 2, London: Thomson Learning, 2009

[15] Hall, C.M. 'Small firms and wine and food tourism in New Zealand': Issues of collaboration, clusters and lifestyles. In R. Thomas (Eds.) Small Firms in Tourism: International Perspectives, Oxford: Elsevier, 2004

[16]Long, L. M. 'Culinary Tourism. Kentucky': The University Press of Kentucky, 2004

[17] Symons, M. 'Gastronomic authenticity and the sense of place', paper presented at the $9^{\text {th }}$ Australian Tourism and Hospitality research Conference for Australian University Tourism and Hospitality Education, 1999

[18]Ryu, K., \& Jang, S. 'Intention to experience local cuisine in a travel destination': the modified theory of reasoned action. Journal of Hospitality and Tourism Research, 30(4), 507-516, 2006

[19] Sparks, B. 'Planning a wine tourism vacation'. Factors that help to predict tourist behavioural intentions. Tourism Management, 28(5), 1180-1192, 2007

[20] Kim, Y. G., Eves, A., \&Scarles, C. 'Building a Model of Local Food Consumption on Trips and Holidays': A Grounded Theory Approach. International Journal of Hospitality Management, 28, 423-431, 2009

[21] Douglas, N., Douglas, N., and Derret, R., (Eds.) 'Special Interest Tourism', Melbourne, Australia: Wiley, 2001

[22] Sharples, N. 'Food in tourism': Attraction and impediment. Annals of Tourism Research, 31, 75-778, 2003

[23] Murcott, A 'You are what you eat' --- Anthropological factors influencing food choice. In: Ritson C, Gofton LR, and McKenzie J (eds.). The Food Consumer. Chichester: John Wiley \& Sons, 107-26, 1986)

[24] Mitchell, R. \& Hall, M. C. 'Consuming tourist: Food tourism consumer behaviour'. In M. C. Hall, L. Sharples, R. Mitchell, N. Macionis\& B. Cambourne (Eds.), Food tourism around the world: Development, management and markets. Oxford and Burlington: Butterworth-Heinemann, 60-80, 2003

[25] Cohen, E., \&Avieli, N. 'Food in Tourism: Attraction and Impediment'. Annals of Tourism Research, 31(4), 755-778, 2004

[26] Cooper, D. R. \& Schindler, P. S. (2001) 'Business research methods'. New York: McGrew-Hill Companies. 


\section{International Journal of Science and Research (IJSR) \\ ISSN (Online): 2319-7064 \\ Index Copernicus Value (2015): 78.96 | Impact Factor (2015): 6.391}

[27] Sauders, M., P. Lewis, D. 'Research Methods for Business Students'. Fourth Harlow, England, FT Prentice Hall, Pearson Education, 2007

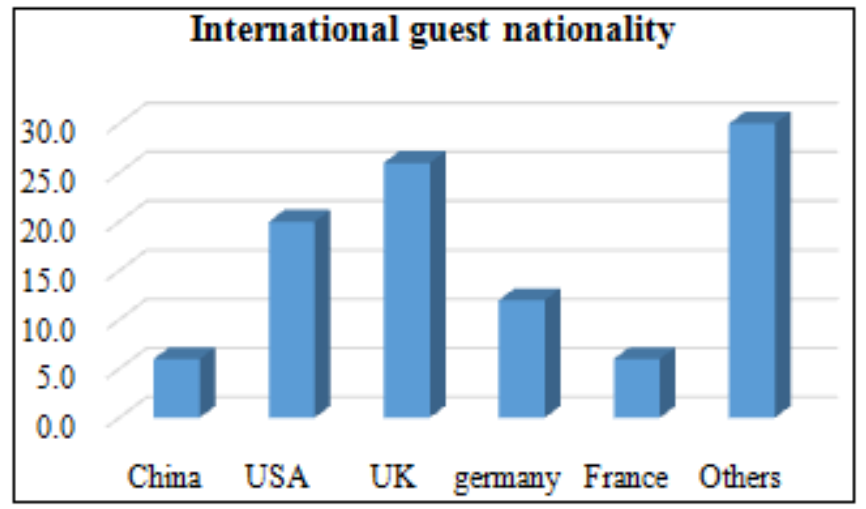

Figure 1: International tourists' nationality

Table 1: Responses from International tourist

\begin{tabular}{|c|c|c|c|}
\hline \multicolumn{2}{|c|}{ variable } & frequency & percent \\
\hline \multirow{2}{*}{ Dishes consumed } & Local dishes & 34 & 68 \\
\hline & Continental dishes & 16 & 32 \\
\hline \multirow{3}{*}{$\begin{array}{l}\text { Type of local food } \\
\text { consumed }\end{array}$} & Fufu \&abunuabunu & 16 & 32 \\
\hline & Kokonte\& palmnut soup & 10 & 20 \\
\hline & Banku \&okro & 24 & 48 \\
\hline \multirow{5}{*}{$\begin{array}{l}\text { Beverages } \\
\text { consumed }\end{array}$} & Pito & 4 & 8 \\
\hline & Asana & 14 & 28 \\
\hline & Palm wine & 7 & 14 \\
\hline & Beer & 15 & 30 \\
\hline & Other & 10 & 20 \\
\hline \multirow{4}{*}{$\begin{array}{l}\text { Motivation for local } \\
\text { foods }\end{array}$} & Reasonable price & 10 & 20 \\
\hline & Familiarity with culture & 12 & 24 \\
\hline & Deliciousness & 11 & 22 \\
\hline & $\begin{array}{l}\text { Excellentcustomer } \\
\text { relationships }\end{array}$ & 17 & 34 \\
\hline \multirow{4}{*}{$\begin{array}{c}\text { How local food } \\
\text { should be different } \\
\text { from regional food }\end{array}$} & Very much & 14 & 28 \\
\hline & Much medium & 6 & 12 \\
\hline & Little & 26 & 52 \\
\hline & Very little & 4 & 8 \\
\hline \multirow{2}{*}{$\begin{array}{c}\text { Knowing the } \\
\text { ingredients before } \\
\text { eating }\end{array}$} & Yes & 38 & 76 \\
\hline & No & 12 & 24 \\
\hline \multirow{4}{*}{$\begin{array}{l}\text { Level of appetite } \\
\text { for local foods }\end{array}$} & Very much & 32 & 64 \\
\hline & Much medium & 4 & 8 \\
\hline & Little & 7 & 14 \\
\hline & Very little & 7 & 14 \\
\hline $\begin{array}{l}\text { Total numberof } \\
\text { respondents }\end{array}$ & & 50 & 100 \\
\hline
\end{tabular}

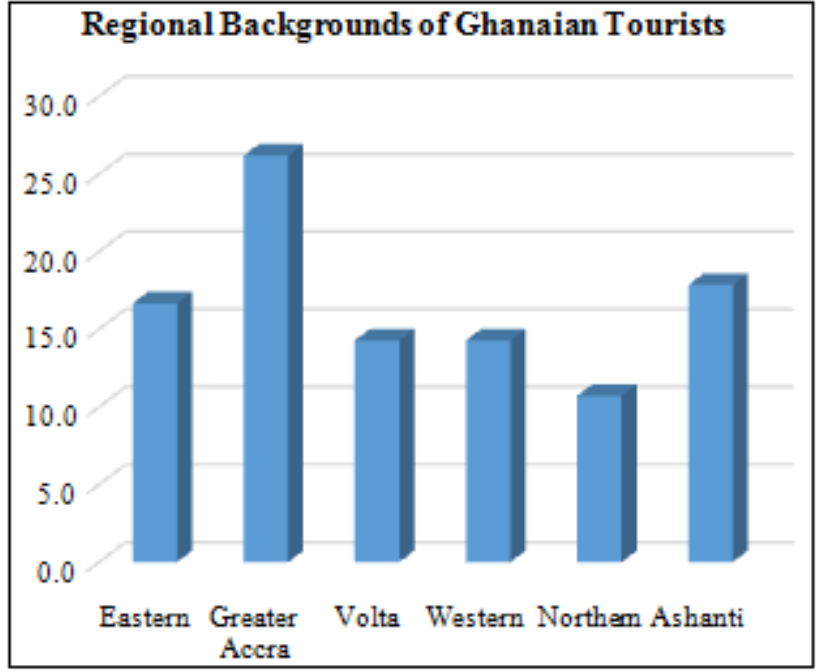

Figure 2: Regional Backgrounds of Local Tourists

Table 2: Response of indigenous Ghanaians

\begin{tabular}{|c|c|c|c|}
\hline \multicolumn{2}{|r|}{ Variable } & Frequency & Percent \\
\hline \multirow{2}{*}{$\begin{array}{c}\text { Dishes } \\
\text { consumed }\end{array}$} & Local dishes & 57 & 67.9 \\
\hline & Continental dishes & 27 & 32.1 \\
\hline \multirow{5}{*}{$\begin{array}{l}\text { Type of local } \\
\text { food consumed }\end{array}$} & Fufu \&abunuabunu & 17 & 20.2 \\
\hline & Kokonte\& palmnut soup & 19 & 22.6 \\
\hline & Banku \&okro & 24 & 28.6 \\
\hline & $\begin{array}{l}\text { Fried ripe plantain and } \\
\text { beans stew }\end{array}$ & 18 & 21.4 \\
\hline & others & 6 & 7.1 \\
\hline \multirow{5}{*}{$\begin{array}{l}\text { Beverages } \\
\text { consumed }\end{array}$} & Pito & 19 & 22.6 \\
\hline & Asana & 18 & 21.4 \\
\hline & Palm wine & 20 & 23.8 \\
\hline & Akpeteshie & 7 & 8.3 \\
\hline & Other & 20 & 23.8 \\
\hline \multirow{4}{*}{$\begin{array}{l}\text { Motivation for } \\
\text { local foods }\end{array}$} & Reasonable price & 23 & 27.4 \\
\hline & Familiarity with culture & 23 & 27.4 \\
\hline & Deliciousness & 20 & 23.8 \\
\hline & $\begin{array}{l}\text { Excellent customer } \\
\text { relationships }\end{array}$ & 18 & 21.8 \\
\hline \multirow{4}{*}{$\begin{array}{l}\text { How local } \\
\text { food should be } \\
\text { different from } \\
\text { regional food }\end{array}$} & Very much & 19 & 22.6 \\
\hline & Much medium & 13 & 15.5 \\
\hline & Little & 30 & 35.7 \\
\hline & Very little & 22 & 26.2 \\
\hline \multirow{2}{*}{$\begin{array}{l}\text { Knowing the } \\
\text { ingredients } \\
\text { before eating }\end{array}$} & Yes & 72 & 85.7 \\
\hline & No & 12 & 14.3 \\
\hline \multirow{4}{*}{$\begin{array}{l}\text { Level of } \\
\text { appetite for } \\
\text { local foods }\end{array}$} & Very much & 49 & 58.3 \\
\hline & Much medium & 15 & 17.9 \\
\hline & Little & 7 & 8.3 \\
\hline & Very little & 13 & 15.5 \\
\hline $\begin{array}{l}\text { Total number } \\
\text { of participant }\end{array}$ & & 84 & 100 \\
\hline
\end{tabular}

